\title{
Potential of Orange Peel Ash as a Cement Replacement Material
}

\author{
Olumide Olu Olubajo ${ }^{1}$, Osha Ade Odey ${ }^{2}$, Basiru Abdullahi ${ }^{1}$
}

${ }^{1}$ Abubakar Tafawa Balewa University

Dass road, P. M. B. 0248, Bauchi, 740272, Nigeria

${ }^{2}$ University of Calabar

Etagbor, P. M. B. 1115, Cross River State, Nigeria

DOI: $10.22178 /$ pos.48-3

LCC Subject Category: QD1-65

Received 28.06.2019

Accepted 25.07.2019

Published online 31.07.2019

Corresponding Author:

Olumide Olu Olubajo

ooolubajo@atbu.edu.ng

(C) 2019 The Authors. This article

is licensed under a Creative

Commons Attribution 4.0 License

(c) (1)

\begin{abstract}
The potential of Orange peel ash (OPA) as a cement replacement material was investigated with focus on the effect of OPA content on the physicomechnical properties such as consistency, setting times, soundness, compressive and flexural strengths of OPA-cement blend for cement replacement between $2.5-10 \%$ at $2.5 \%$ interval. The optimal calcination temperature and time of orange peel (OP) was achieved by calcining the $\mathrm{OP}$ at various temperature between $\left(600^{\circ} \mathrm{C}, 700^{\circ} \mathrm{C}, 800^{\circ} \mathrm{C}\right)$ and time $(1 \mathrm{hr}$. and $2 \mathrm{hrs}$.) respectively. The chemical compositions of the various orange peel ashes were determined using $\mathrm{X}$-ray fluorescence equipment and the optimal conditions was obtained at $600{ }^{\circ} \mathrm{C}$ and 2 hours. The consistency and setting time tests were conducted with a Vicat apparatus on the binary cement pastes in accordance to ASTM standards. Results indicated an increase in the water required for consistency as the OPA content was increased from $2.5-10 \%$ which was attributed to the unburnt carbon content present in the ash. Similarly, a gradual increase in the cement replacement with OPA resulted in a prolonged setting time which was could be attributed to the diminution of the clinker content and the higher water requirement for normal consistence. The soundness of the OPA cement blend experienced an increase in free lime content as the OPA content rose from $2.5-10 \%$. Both compressive and flexural strengths were found to decrease as the OPA content was gradually increased whereas an increase in the strengths were observed as the curing days progressed. It was also observed that $5 \%$ cement replacement with OPA did not adversely affect the strength in comparison to the OPC control due to the pozzolanic reaction which resulted in the enhanced strengths especially at 28 days.
\end{abstract}

Keywords: orange peel ash; cement replacement; normal consistency; setting times; soundness compressive strength and flexural strength; curing days.

\section{INTRODUCTION}

The development of a nation is not solely dependent on its technological insights but also its infrastructure [27]. Thus, concrete has become an indispensable material in the construction industry. The advent of cement/concrete has given rise to making life comfortable and worthwhile through the construction of flyovers, skyscrapers, bridges, dams, and various buildings ranging from hospitals, factories, etc [33]. Cement is one of the most essential components in the production of concrete which gives it, its strong bonding ability and consisting [2]. The global orange production in 2017 is estimated at 89 million tons [34] while its industrial waste is estimated at $15 \times 106$ tons [24]. These industrial by-products comprise of peels, seeds, and pulp membrane residues [22]. The orange peels importance ranging from perfume, cosmetics, antiviral, antifungal and antibacterial properties due to the presence of limonoids $[13,23]$, others include biogas and ethanol production [11]. The increase in world population has driven and propelled the need for increased agricultural production globally [32], thus, generating enormous industrial and agro wastes can result in environmental disposal issues [25]. It is in a bid to solve these environmental waste disposal concerns via the use of the agro-wastes which can be converted for use in cement. Similarly, the high cost and demand for cement have driven researcher to sort for an alternative for cement replacement with agricultural wastes such as orange-peel ash, rice husk ash, corn cob ash, etc. Several research works have been investigated with various successes 
include rice husk ash [9], coal bottom ash [19, 30, 15], fly ash [15, 10], corn cob ash [31], eggshell ash $[16,35]$, etc. A study on the effect of replacing cement with the ash from the calcination of orange peel on the physicomechanical properties of cement should be investigated.

Wastes are those materials which no longer have a use by industry or institution and considered as by-products of production and consumption processes. The main source of these waste includes municipal, industrial (mining and quarry waste), agricultural (animal and forestry), construction/demolition, etc. [8]. Solid wastes include domestic refuse, commercial and institutional wastes, construction debris, human wastes, ashes from incinerators, sludge, sewage and agricultural waste [21]. Large amounts of orange peels are disposed of in large quantities as waste product annually in many countries [18] including Nigeria. Contamination of water bodies through improper disposal of agro-waste and the huge cost implication in the cement industry have become a growing concern. Owing to the huge demand for cement and high energy/production cost has resulted in the use of orange peel as an alternative fuel for linearization which did not adversely affect the quality of cement according to works by [33]. Disposal of agricultural waste materials such as rice husk, groundnut husk, corn cob, coconut shell, and orange peel can constitute environmental issues, hence the need to convert these wastes to useful materials to minimize their negative effect on the environment [1].

Pozzolans according to American Standard Testing Methods (ASTM) standard, are defined as siliceous or aluminous materials which possess little or no cementitious properties but will in the presence of moisture react with lime at ordinary temperature to form a compound with pozzolanic properties. Such pozzolanic materials include fly ash, coal bottom ash, calcined diatomaceous earth, rice husk ash, pulverized burnt clay, etc. Various research works have shown that calcined agro-wastes are mainly rich in amorphous silica and could be employed as a partial cement replacement and also established that the amorphous silica present possesses pozzolanic properties which react with lime readily compared to crystalline silica. This reaction has led to improved compressive strength which is an agreement with coal bottom ash cement blend from
$[19,30]$, rice husk ash $[9,17,26]$ and fly ash cement blend [10].

Orange peel is a global agro/industrial waste residue of the orange-juice and soft-drink industries [28]. Orange peel possesses a cellulosic structure which contains amino-acids. Thus, it is a good bio-sources of essential oil. Orange peel is usually considered as waste can cause allergies when kept in waste for long periods as well as produce undesirable odor which irritates, thus proper disposal is essential. Calcined Orange peel is composed mainly of lime and silica while other minor components include Magnesium, Aluminium, Phosphorous, Sodium, Potassium, and Iron among others. One of the challenges of the availability of orange peel to be employed as a cement replacement is its orange production is seasonal. Studies had indicated that the composition of ash of orange peel is slightly similar to OPC with high silica, lime, and Potassium content. The effect of a number of pozzolans on the physicomechanical properties of cement has been studied such as metakaolin (MK), rice husk ash (RHA), coal bottom ash (CBA), fly ash (FA), limestone (L), sawdust ash (SDA) and Eggshell powder (ESP) etc. $[30,15,10,31,16,12,29,21,35]$ with various successes. Researches are geared towards investigating the potential applicability of OPA from the calcination of orange peel as a cement replacement to improve their physical and mechanical properties of cement blend, reduce the cost of cement [30] and as a source of energy [32].

This research work tries to investigate the potentials of employing calcined orange peel waste as a cement replacement up to $10 \%$ to explore the effects on the physicomechanical properties of cement blended with orange peel ash. This scope of this research work involves the characterization of the starting materials such as OPA and OPC using X-ray Fluorescence technique, determination of the physical and mechanical properties such as consistency, setting times, soundness, the compressive and flexural strength of cement blends according to [4]. It also tries to provide an optimum cement replacement for the orange peel to be employed as a cement replacement without hurting the cement properties which will also contribute immensely to the future advancement in the green cement production thus, eliminating the use of other additives. 


\section{MATERIALS AND METHODS}

Materials used in this study include ordinary Portland cement CEM I 42.5R obtained by Ashaka cement company Plc, a subsidiary of Lafarge cement and the orange peel which was obtained from various places in Warji, Bauchi state. The orange peels were collected and sorted to ensure that other debris were removed. The sorted orange peels were air-dried in the sun to reduce its moisture content. The dried orange peels were burnt at various temperatures and times to establish the optimal temperature and time for the production of OPA. The OPA underwent size reduction with 75-micron sieve and the chemical composition of the ash was characterized using X-ray fluorescence technique.

The Vicat apparatus shown in Figure 1 was employed to determine the standard consistency for both ordinary Portland cement and the binary blends pastes. Three hundred grams (300 g) of the OPC and OPA cement blends were measured and gauged with a specific quantity of water until the resistance to penetration of a plunger reaches about not less $10 \mathrm{~mm}$ within 30 minutes according to [3]. The ratio of the water required to the weight of the binder expressed as a percentage is taken as the standard consistency of the cement or blend.

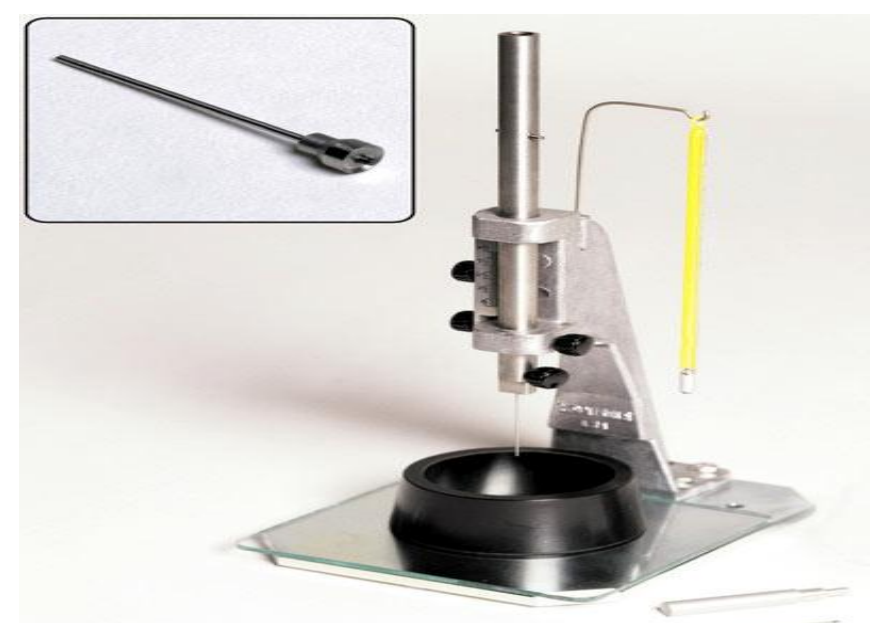

Figure 1 - Vicat apparatus

Similarly, the Vicat apparatus was used in the determination of setting time of cement blends using [6]. This is achieved by using the percentages of water recorded from the standard consistency of the cement / blend paste which was gauged into the Vicat mould. The paste confined in the mould on a base plate was then placed under the Vicat apparatus with a needle provided for the initial setting time determination in place. The needle was then lowered gently until contact was made with the surface of the test block and quickly released and allowed to sink in. This process was repeated until the needle does not penetrate beyond $4 \mathrm{~mm}$ from the bottom of the mould. The period elapsed between the time when the water was added to the cement and the time at which the needle ceased to descend beyond $4 \mathrm{~mm}$ from the bottom of the test block was noted as the initial setting time. In the case of the final setting time, the needle used for the initial setting time was replaced by a needle with annular attachment.

The cement pastes were considered to set finally when upon applying the needle gently on the surface of the test block, only when the needle made an impression while the attachment fails to do so. The time from gauging, at which the needle ceased to pierce the test block was noted as the final setting time.

Soundness refers to the ability of hardened cement paste to retain its volume after setting and determines if the cement sample contains excessive amount of burnt free lime or magnesium. $750 \mathrm{mg}$ of OPA was weighed into a conical flask and $30 \mathrm{ml}$ of glycol was added and shaken properly. After which the conical flask with the mixture was placed in a water bath for 15 minutes. The solution was then filtered through a Buchner funnel connected to the section pump and rinsed with $30 \mathrm{ml}$ of methylated spirit. 2 to 3 drops of Bromocresol green indicator was added into the filtrate and shook to dilution. Then titration was conducted with $0.1 \mathrm{~N} \mathrm{HCl}$, till the color changes from blue to yellowish green. The adverse effect of high free lime in cement leads to expansion at high temperatures resulting in cracks in buildings.

The compressive strength test was conducted on the cement mortar which was prepared by mixing $450 \mathrm{~g}$ of cement with $225 \mathrm{ml}$ of water and $1350 \mathrm{~g}$ of standard sand in a mixing machine at $20{ }^{\circ} \mathrm{C}$ with relative humidity not less than $50 \%$. After proper mixing the mortar, the mix was transferred into the $40 \mathrm{~mm} \times 40 \mathrm{~mm} \times 160 \mathrm{~mm}$ moulds and compacted using a standard jolting apparatus and kept in a cabinet for 24 hours. The moulds were then demoulded and placed in curing tank containing water until the strength testing for the required days. The specimen was then broken into two by bending test to obtain the flexural strength while each half was tested for compressive strength using the Toni Technik 
compression and bending machine. The loading sequence must not be less than 20 seconds and should not exceed 80 seconds. The experimental matrix for the determination of the physical and mechanical properties of ordinary Portland cement and Orange peel ash cement blends are tabulated in Table 1.

Table 1 - Experimental matrix for OPA cement blend physicomechnical properties

\begin{tabular}{|l|l|c|c|}
\hline No & Cement Blends & OPC, $\%$ & OPA, $\%$ \\
\hline 1 & OPC & 100 & 0 \\
\hline 2 & $2.50 P A$ & 97.5 & 2.5 \\
\hline 3 & 5OPA & 95 & 5 \\
\hline 4 & $7.50 P A$ & 92.5 & 7.5 \\
\hline 5 & $100 P A$ & 90 & 10 \\
\hline
\end{tabular}

\section{RESULT AND DISCUSSION}

The chemical composition of calcined orange peel was determined using X-ray fluorescence at $600{ }^{\circ} \mathrm{C}, 700{ }^{\circ} \mathrm{C}$ and $800{ }^{\circ} \mathrm{C}$ for 1 and 2 hrs respectively are tabulated in Table 2 . The orange peel ashes contain mainly oxides such as silica, lime and Potassium oxide. Figure 2 depicts the samples of calcined orange peel at various temperatures and times.
Table 2 - Chemical Composition of OPA at various Temperature and Time

\begin{tabular}{|c|c|c|c|c|c|c|}
\hline \multirow[t]{2}{*}{ Oxide } & \multicolumn{2}{|c|}{$600^{\circ} \mathrm{C}$} & \multicolumn{2}{|c|}{$700^{\circ} \mathrm{C}$} & \multicolumn{2}{|c|}{$800^{\circ} \mathrm{C}$} \\
\hline & $1 \mathrm{hr}$ & $2 \mathrm{hr}$ & $1 \mathrm{hr}$ & $2 \mathrm{hr}$ & $1 \mathrm{hr}$ & $2 \mathrm{hr}$ \\
\hline $\mathrm{iO}_{2}$ & 22.47 & 3.28 & 16.60 & 22.69 & 23.72 & 23.31 \\
\hline $\mathrm{Al}_{2} \mathrm{O}_{3}$ & 1.94 & 2.31 & -0.44 & 2.34 & 2.28 & 1.99 \\
\hline $\mathrm{Fe}_{2} \mathrm{O}_{3}$ & 1.29 & 2.11 & 0.85 & 1.66 & 1.66 & 1.77 \\
\hline $\mathrm{aO}$ & 29.38 & 31.01 & 27.14 & 28.13 & 30.11 & 31.65 \\
\hline IgO & 3.63 & 3.83 & 3.23 & 3.87 & 4.01 & 4.00 \\
\hline $\mathrm{SO}_{3}$ & 0.52 & 0.80 & 0.27 & 0.80 & 0.31 & 0.94 \\
\hline $\mathrm{K}_{2} \mathrm{O}$ & 24.48 & 26.27 & 21.23 & 23.43 & 24.46 & 26.08 \\
\hline $\mathrm{a}_{2} \mathrm{O}$ & 10 & 35 & 0.32 & 0.36 & 0.37 & 1.18 \\
\hline $\mathrm{P}_{2} \mathrm{O}_{5}$ & 2.10 & 2.62 & 68 & 2.46 & 2.50 & 2.75 \\
\hline $\mathrm{n}_{2} \mathrm{O}_{3}$ & 27 & 28 & 0.30 & 0.28 & 0.32 & 0.31 \\
\hline $\mathrm{TiO}_{2}$ & 32 & 0.32 & 0.31 & 0.27 & 0.34 & 0.33 \\
\hline $\mathrm{Cl}$ & 0.03 & 0.03 & 0.03 & 0.02 & 0.04 & 0.13 \\
\hline $\mathrm{Cr}_{2} \mathrm{O}_{3}$ & 02 & 0.01 & 0.00 & 0.03 & 0.01 & 0.01 \\
\hline SrO & 0.23 & 0.24 & 0.16 & 0.22 & 0.22 & 0.24 \\
\hline LOI & 12.91 & 6.54 & 28.41 & 13.45 & 9.67 & 5.30 \\
\hline Total & 100.00 & 100.00 & 100.00 & 100.00 & 100.00 & 100.00 \\
\hline $\begin{array}{l}\mathrm{SiO}_{2} \\
+\mathrm{Al}_{2} \mathrm{O}_{3} \\
+\mathrm{Fe}_{2} \mathrm{O}_{3}\end{array}$ & 25.70 & 27.70 & 17.01 & 26.69 & 27.66 & 27.08 \\
\hline $\begin{array}{l}\mathrm{SiO}_{2} \\
+\mathrm{Al}_{2} \mathrm{O}_{3} \\
+\mathrm{Fe}_{2} \mathrm{O}_{3}\end{array}$ & 55.08 & 58.71 & 44.15 & 54.82 & 57.77 & 58.73 \\
\hline
\end{tabular}

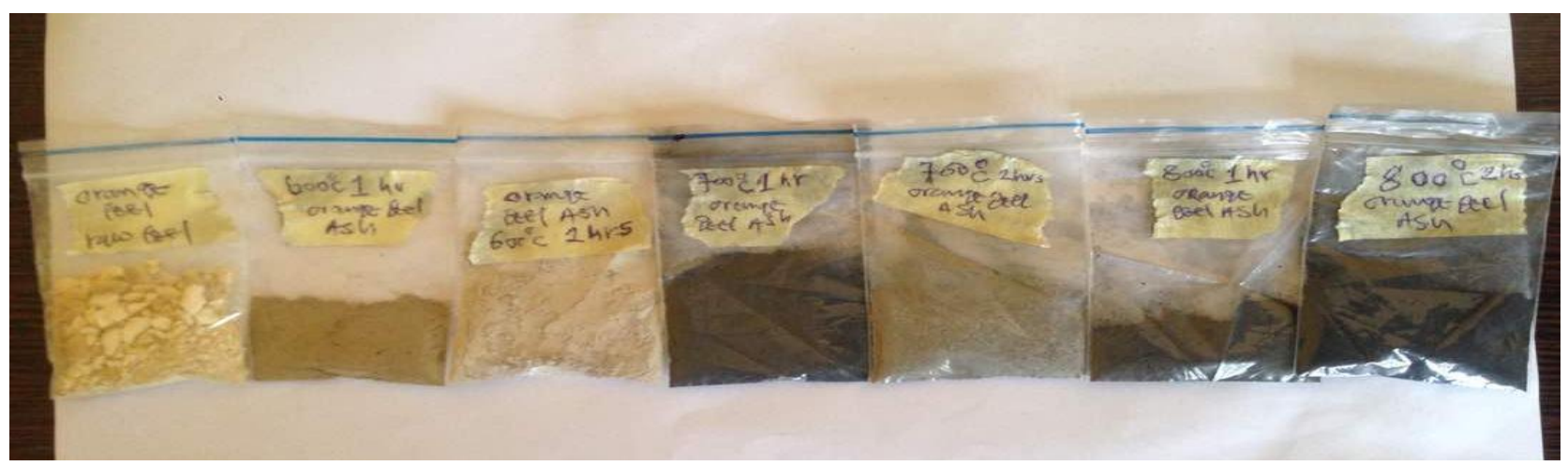

Figure 2 - Calcined orange peel at various temperature and time

Table 3 shows the chemical composition of ordinary Portland cement and orange peel ash via Xray Fluorescence analysis. Chemical analysis revealed that orange peel calcined at $600{ }^{\circ} \mathrm{C}$ for 2 hours contained less than $70 \%$ of $\mathrm{SiO}_{2}+$ $\mathrm{Al}_{2} \mathrm{O}_{3}+\mathrm{Fe}_{2} \mathrm{O}_{3}(27.70 \%)$ while $\mathrm{CaO}$ content was $31 \%$ which met class $\mathrm{C}$ with $\mathrm{CaO}$ content $>10 \%$, hence the ash does not satisfy as a pozzolan according to [7]. The OPA had a loss on ignition of $6.54 \%$ which indicates a high degree of unburnt carbon of ash [20] which is also responsible for increase in the water requirement due to the high porosity of the OPA particle resulting in mixture segregation $[19,29,5]$.

Effect of OPA content on the Water demand / Consistency of cement blend. Table 4 indicates the effect of OPA content on the water consistency, initial and final setting times of cement blends while Figure 1 presents the effect of cement replacement with OPA on the water requirement at standard consistence for OPA cement blends. 
Table 3 - Chemical composition of ordinary Portland cement (OPC) and orange peel ash (OPA)

\begin{tabular}{|c|c|c|}
\hline Oxides & OPC, $\%$ & OPA, $\%$ \\
\hline $\mathrm{SiO}_{2}$ & 19.86 & 23.3 \\
\hline $\mathrm{Al}_{2} \mathrm{O}_{3}$ & 6.44 & 2.31 \\
\hline $\mathrm{Fe}_{2} \mathrm{O}_{3}$ & 2.96 & 2.11 \\
\hline $\mathrm{CaO}$ & 65.02 & 31.00 \\
\hline $\mathrm{MgO}$ & 0.98 & 3.83 \\
\hline $\mathrm{SO}_{3}$ & 1.62 & 0.80 \\
\hline $\mathrm{K}_{2} \mathrm{O}$ & 0.96 & 26.26 \\
\hline $\mathrm{Na}_{2} \mathrm{O}$ & 0.13 & 0.35 \\
\hline $\mathrm{P}_{2} \mathrm{O}_{5}$ & 0.18 & 2.62 \\
\hline $\mathrm{Mn}_{2} \mathrm{O}_{3}$ & 0.17 & 0.28 \\
\hline $\mathrm{TiO}_{2}$ & 0.30 & 0.32 \\
\hline $\mathrm{Cl}$ & 0.01 & 0.03 \\
\hline $\mathrm{Cr}_{2} \mathrm{O}_{3}$ & 0.48 & 0.01 \\
\hline $\mathrm{SrO}$ & - & 0.24 \\
\hline LOI & & 6.54 \\
\hline $\mathrm{C}_{3} \mathrm{~S}$ & 66.21 & -69.47 \\
\hline $\mathrm{C}_{2} \mathrm{~S}$ & 7.00 & 119.21 \\
\hline $\mathrm{C}_{3} \mathrm{~A}$ & 12.06 & 2.55 \\
\hline $\mathrm{C}_{4} \mathrm{AF}$ & 9.01 & 6.42 \\
\hline $\mathrm{SiO}_{2}+\mathrm{Al}_{2} \mathrm{O}_{3}+\mathrm{Fe}_{2} \mathrm{O}_{3}$ & & 27.70 \\
\hline Moisture content \% & - & 18.67 \\
\hline Blaine Fineness $\mathrm{cm}^{2} / \mathrm{g}$ & 4620 & 4240 \\
\hline
\end{tabular}

Table 4 - Effect of OPA content on the normal consistence, water demand and setting times of OPA cement blend

\begin{tabular}{|c|c|c|c|c|}
\hline $\begin{array}{c}\text { OPA } \\
\text { content, } \\
\%\end{array}$ & $\begin{array}{c}\text { Water } \\
\text { consistency, } \\
\%\end{array}$ & $\begin{array}{c}\text { Water } \\
\text { demand, } \\
\text { mm }\end{array}$ & $\begin{array}{c}\text { Initial } \\
\text { setting } \\
\text { time, } \\
\text { mins }\end{array}$ & $\begin{array}{c}\text { Final } \\
\text { setting } \\
\text { time, } \\
\text { mins }\end{array}$ \\
\hline 0.0 & 28.60 & 85.8 & 120 & 148 \\
\hline 2.5 & 29.80 & 89.4 & 126 & 152 \\
\hline 5.0 & 34.20 & 102.6 & 136 & 164 \\
\hline 7.5 & 38.60 & 115.8 & 148 & 198 \\
\hline 10.0 & 42.40 & 127.2 & 152 & 224 \\
\hline
\end{tabular}

As shown in Figure 3, an increase in the water consistence of OPA-PC paste with increase in the OPA content. It could also be observed that as the water demand increased from $89.4 \mathrm{~mm}$ to $127.2 \mathrm{~mm}$ as the OPA content increased from $2.5 \%$ to $10 \%$. The OPA-cement blends required more water demand for normal consistence in comparison with OPC control. The OPA was found to possess a higher burnt carbon content with a LOI value of $6.54 \%$ than required from [7] standards. This high unburnt carbon can increase the water requirement for normal consistence which agrees with research works of $[19,15,29]$.

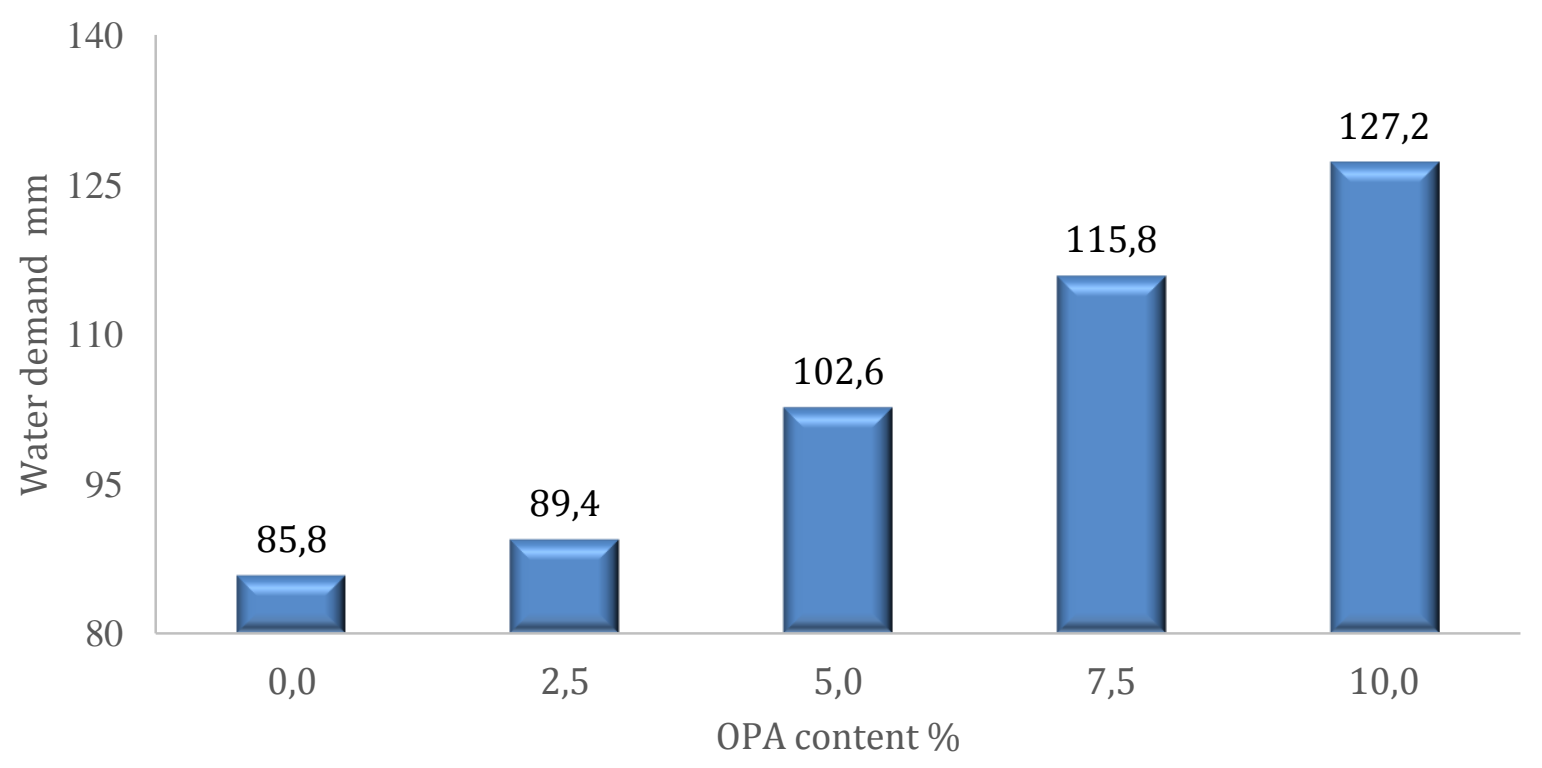

Figure 3 - Effect of OPA content on the water demand of binary cement blend

Similarly, the consistency of the OPA cement blend varied from $29.80-42.40 \%$ as the OPA content increased from $2.5 \%$ to $10 \%$. Another reason for the increase in the consistency of the OPA cement blend in comparison to control could also be due to the porous and rough morphology of the OPA.
Effect of OPA content on the Setting times of cement blend. The initial and final setting times of OPC were found to be lower than OPA cement blend at various cement replacements. As the OPA content rise from $2.5 \%$ to $10 \%$ by weight of the cement, its initial and final setting time increased 
by $20.64 \%$ and $47.37 \%$ respectively (Figure 4 ). The elongation of the setting time of OPA cement blends compared to OPC could be attributed to the diminution of clinker content as a result of a decrease in calcium silicate. This increase in the setting times could also be due to the high-water requirement owing to presence of unburnt carbon which agrees with works by $[19,15,29]$.

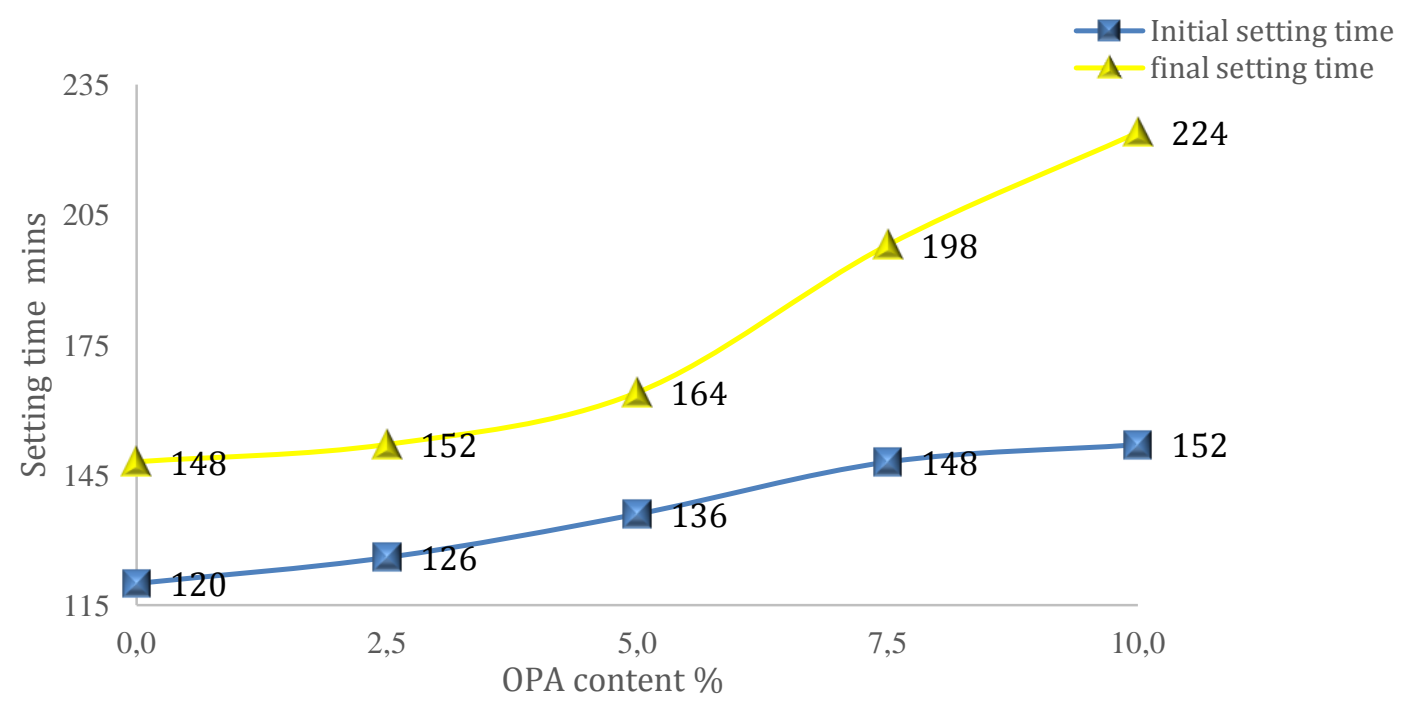

Figure 4 - Effect of cement replacement on the setting time of OPA cement blends

The OPA cement blend up to $10 \%$ replacement retarded the initial and final setting time by 32 minutes and 76 minutes respectively in comparison with OPC control. The results of both setting times of the OPA cement blend presented in Table 4 were within the limit as recommended by [5].

Effect of OPA on the Blaine fineness of OPA cement blends. The effect of OPA content on the Blaine fineness, specific gravity and free lime content of OPA cement blends are presented in Table 5 while Figure 5 shows the pictorial diagram of the Blaine fineness apparatus.

Table 5 - Variation of OPA content on the Blaine fineness and free lime of the various cement blends

\begin{tabular}{|c|c|c|c|}
\hline $\begin{array}{c}\text { OPA, } \\
\%\end{array}$ & $\begin{array}{c}\text { Blaine Fineness } \\
\mathrm{m} 3 / \mathrm{kg}\end{array}$ & $\begin{array}{c}\text { Specific } \\
\text { gravity }\end{array}$ & $\begin{array}{c}\text { Free } \\
\text { lime }\end{array}$ \\
\hline 0 & 476.0 & 3.08 & 1.50 \\
\hline 2.5 & 475.2 & 3.04 & 1.59 \\
\hline 5.0 & 474.4 & 3.01 & 1.69 \\
\hline 7.5 & 473.5 & 2.97 & 1.78 \\
\hline 10.0 & 472.7 & 2.93 & 1.87 \\
\hline
\end{tabular}

The Blaine fineness of OPA blended cements were found to be lower compared to the ordinary Portland cement Blaine fineness. The Blaine fineness and the specific gravity of the OPA cement blend were found to decrease with increase in the OPA content which is attributed to the higher Blaine fineness and specific gravity of OPC compared to OPA respectively.

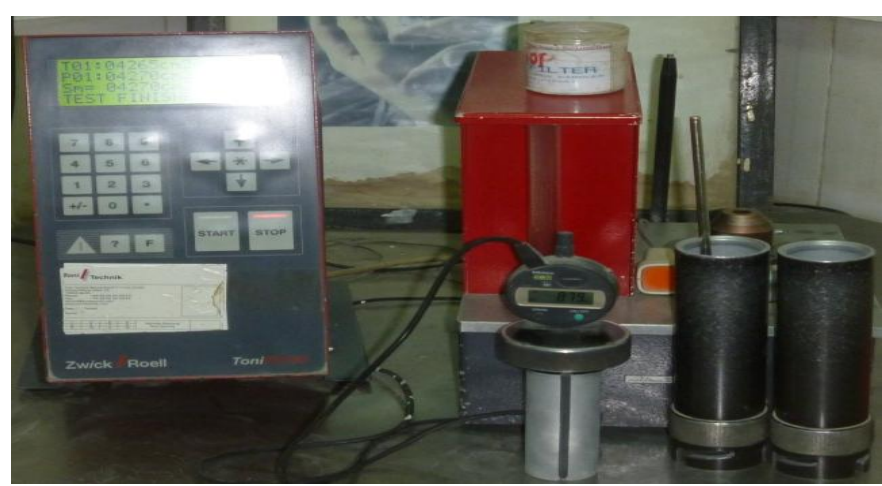

Figure 5 - Blaine Apparatus

Effect of OPA content on the mortar strength of cement blend. The effect of OPA content on the mortar compressive and flexural strength of cement blends are tabulated in Table 6. A decrease in the compressive strength of cement blended with OPA were observed as the OPA content was gradually increased from $2.5-10 \%$. This reduction in the strengths of the OPA cement blends could be attributed to the high-water requirements of the OPA cement blend due to high unburnt carbon in the ash and dilution of Portland cement compounds which results in reduced compressive and flexural strength especially at high cement replacement of $10 \%$ OPA at 28 days (60.1\%). 
Table 6 - Effect of OPA content on the Mortar compressive and flexural strengths of OPA cement blends at various cement replacement

\begin{tabular}{|c|c|c|c|c|}
\hline $\begin{array}{c}\text { OPA } \\
\text { content \% }\end{array}$ & $\begin{array}{c}2 \text { days } \\
(\mathrm{MPa})\end{array}$ & $\begin{array}{c}7 \text { days } \\
(\mathrm{MPa})\end{array}$ & $\begin{array}{c}28 \text { days } \\
(\mathrm{MPa})\end{array}$ & $\begin{array}{c}60 \text { days } \\
(\mathrm{MPa})\end{array}$ \\
\hline 0.0 & 32.29 & 41.14 & 45.24 & 54.46 \\
& $(5.31)$ & $(6.34)$ & $(6.46)$ & $(7.38)$ \\
\hline 2.5 & 37.67 & 39.49 & 41.14 & 49.41 \\
& $(5.22)$ & $(6.32)$ & $(6.34)$ & $(7.13)$ \\
\hline 5.0 & 20.84 & 37.37 & 44.41 & 45.24 \\
& $(3.87)$ & $(5.22)$ & $(6.53)$ & $(6.73)$ \\
\hline 7.5 & 26.37 & 34.21 & 37.67 & 39.49 \\
& $(4.90)$ & $(5.67)$ & $(5.22)$ & $(6.32)$ \\
\hline 10.0 & 9.63 & 15.21 & 17.24 & 23.83 \\
& $(2.37)$ & $(3.16)$ & $(3.81)$ & $(4.95)$ \\
\hline
\end{tabular}

Figure 6 depicts the mortar compressive strength testing machine while Figures 7 and 8 illustrate the influence of OPA content on the compressive and flexural strengths for various OPA-OPC mortars respectively.

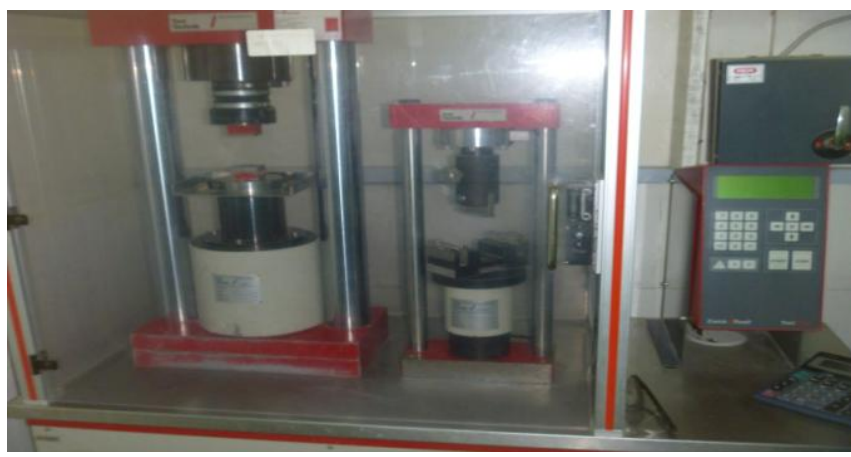

Figure 6 - Compressive Strength Testing Machine

The mortar strengths of the cement blends were found to be lower than those of the OPC control. This can be attributed to the clinker diminution since calcium silicates are responsible for strength $[15,10,29,21]$. The mortar compressive and flexural strengths of the OPA cement blends and OPC control experienced an increase as the curing age progressed from 2 to 60 days. It was also observed that as the cement replacement level of the OPA was gradually increased from 2.5 to $10 \%$ at a given curing time, most of their compressive and flexural strengths diminished.

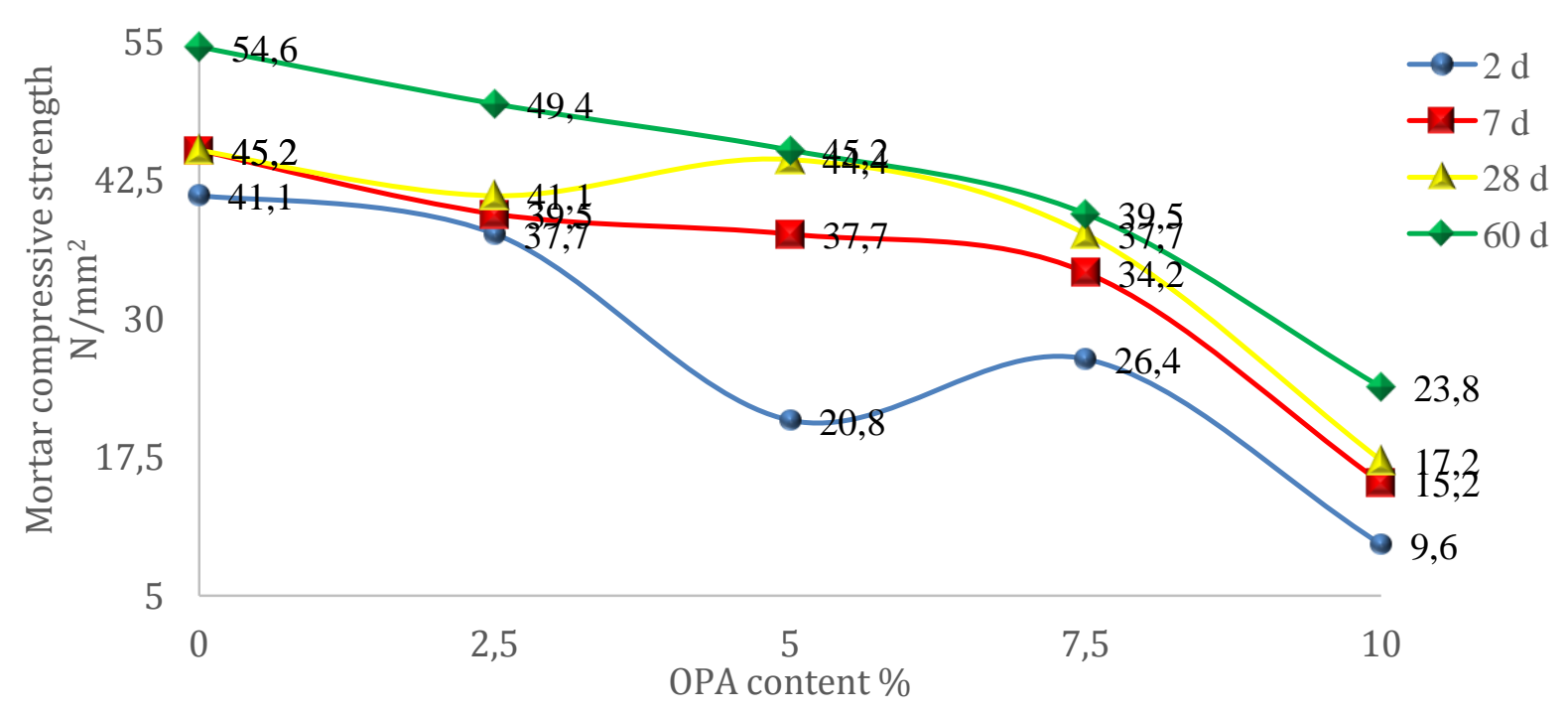

Figure 7 - Effect of OPA content on the mortar compressive strength of cement blends

These reductions could be due to diminution of the clinker content and a higher water requirement to attain consistence which results in reduced strengths in comparison with control. 90 and $95 \%$ of the mortar compressive strength of 28 days control compressive strength was achieved for 2.5 and $5 \%$ cement replacement with OPA respectively and thus the optimal OPA cement replacement should not exceed 5\%. At $5 \%$ cement replacement with OPA, it could be observed that despite the reduced strength at 2 days in comparison with OPC control, the compressive strength was significantly enhanced from 28.84 to $44.41 \mathrm{MPa}$ which was $80 \%$ at 28 days. This enhanced strength could be due to pozzolanic activity as a result of silica presence in the OPA along with available excess lime resulting in the formation of more $\mathrm{CSH}$ which was responsible for enhanced strengths [30]. 


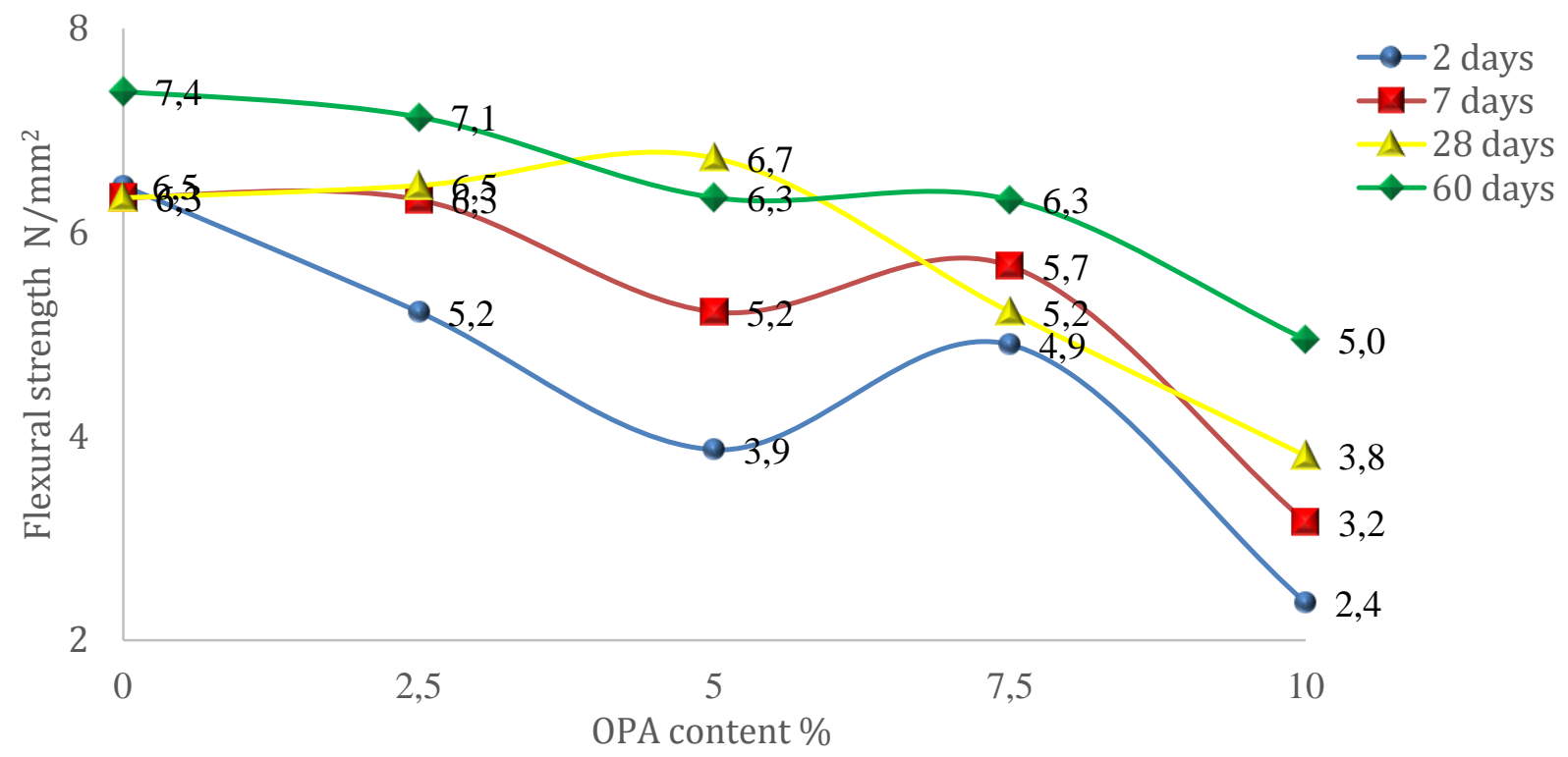

Figure 8 - Effect of OPA content on the flexural strength of cement blends

Table 7 presents the compressive strength of OPA cement blend expressed as a percentage rate of that of OPC at the same curing age. Cement replacement of $2.5 \%$ at 2,7, 28 and 60 days produced percentage compressive strength approximately $92 \%, 87 \%, 91 \%$ and $91 \%$ of the control' compressive strength respectively.

Table 7 - Compressive and flexural strengths of OPA cement blends as a percentage of OPC

\begin{tabular}{|c|c|c|c|c|}
\hline $\begin{array}{c}\text { OPA } \\
\text { content, } \\
\%\end{array}$ & $\begin{array}{c}2 \text { days } \\
(\mathrm{MPa})\end{array}$ & $\begin{array}{c}7 \text { days } \\
(\mathrm{MPa})\end{array}$ & $\begin{array}{c}28 \text { days } \\
(\mathrm{MPa})\end{array}$ & $\begin{array}{c}60 \text { days } \\
(\mathrm{MPa})\end{array}$ \\
\hline 0.0 & $\begin{array}{c}100.0 \\
(100.0)\end{array}$ & $\begin{array}{c}100.0 \\
(100.0)\end{array}$ & $\begin{array}{c}100.0 \\
(100.0)\end{array}$ & $\begin{array}{c}100.0 \\
(100.0)\end{array}$ \\
\hline 2.5 & $\begin{array}{c}91.6 \\
(80.8)\end{array}$ & $\begin{array}{c}87.3 \\
(99.7)\end{array}$ & $\begin{array}{c}90.9 \\
(101.9)\end{array}$ & $\begin{array}{c}90.6 \\
(96.6)\end{array}$ \\
\hline 5.0 & $\begin{array}{c}50.7 \\
(59.9)\end{array}$ & $\begin{array}{c}83.3 \\
(82.3)\end{array}$ & $\begin{array}{c}98.2 \\
(106.2)\end{array}$ & $\begin{array}{c}82.9 \\
(85.6)\end{array}$ \\
\hline 7.5 & $\begin{array}{c}64.1 \\
(75.9)\end{array}$ & $\begin{array}{c}75.6 \\
(89.4)\end{array}$ & $\begin{array}{c}83.3 \\
(82.3)\end{array}$ & $\begin{array}{c}72.4 \\
(85.6)\end{array}$ \\
\hline 10.0 & $\begin{array}{c}23.4 \\
(36.7)\end{array}$ & $\begin{array}{c}33.6 \\
(49.8)\end{array}$ & $\begin{array}{c}38.1 \\
(60.1)\end{array}$ & $\begin{array}{c}43.7 \\
(67.1)\end{array}$ \\
\hline
\end{tabular}

The percentage compressive strength of OPA cement blend for $5 \%$ cement replacement compared with OPC at 2, 7, 28 and 60 curing days were $51 \%, 83 \%, 98 \%$ and $83 \%$ producing compressive value very close to the control at 28 days. For $7.5 \%$ cement replacement of OPA produced percentage compressive strength to con- trol of $64 \%, 75 \%, 83 \%$ and $72 \%$ for $2,7,28$ and 60 days respectively. At $10 \%$ cement replacement with OPA produced very low compressive strength rate below $50 \%$ for 2 and 7 days. Similar trend was observed for the flexural strength of OPA cement blend as a percentage of OPC control.

Effect of OPA content on the soundness of cement blend. The soundness (expansion) of the OPA cement blends were tested using the titration method. Table 5 tabulates the effect of OPA content on the free lime content of various cement blends.

It could be seen from Figure 9 that as the cement replacement with OPA increased from $2.5 \%$ to $10 \%$ by wt., the free lime content increased. This increase is due to the high lime content $(31.00 \%)$ present in the OPA.

The free lime content increase from $1.59 \%$ to $1.87 \%$ as the OPA content was an increase from $2.5 \%$ cement replacement up to $10 \%$ cement replacement of the orange peel ash (OPA), while the free lime of ordinary Portland cement (OPC) was $1.5 \%$. The maximum allowable percentage of the free lime (free $\mathrm{CaO}$ ) is $2.5 \%$ and the minimum percentage is $1.0 \%$.

The results clearly indicated that the addition up to $10 \%$ of the OPA will not cause the expansion in the cement. 


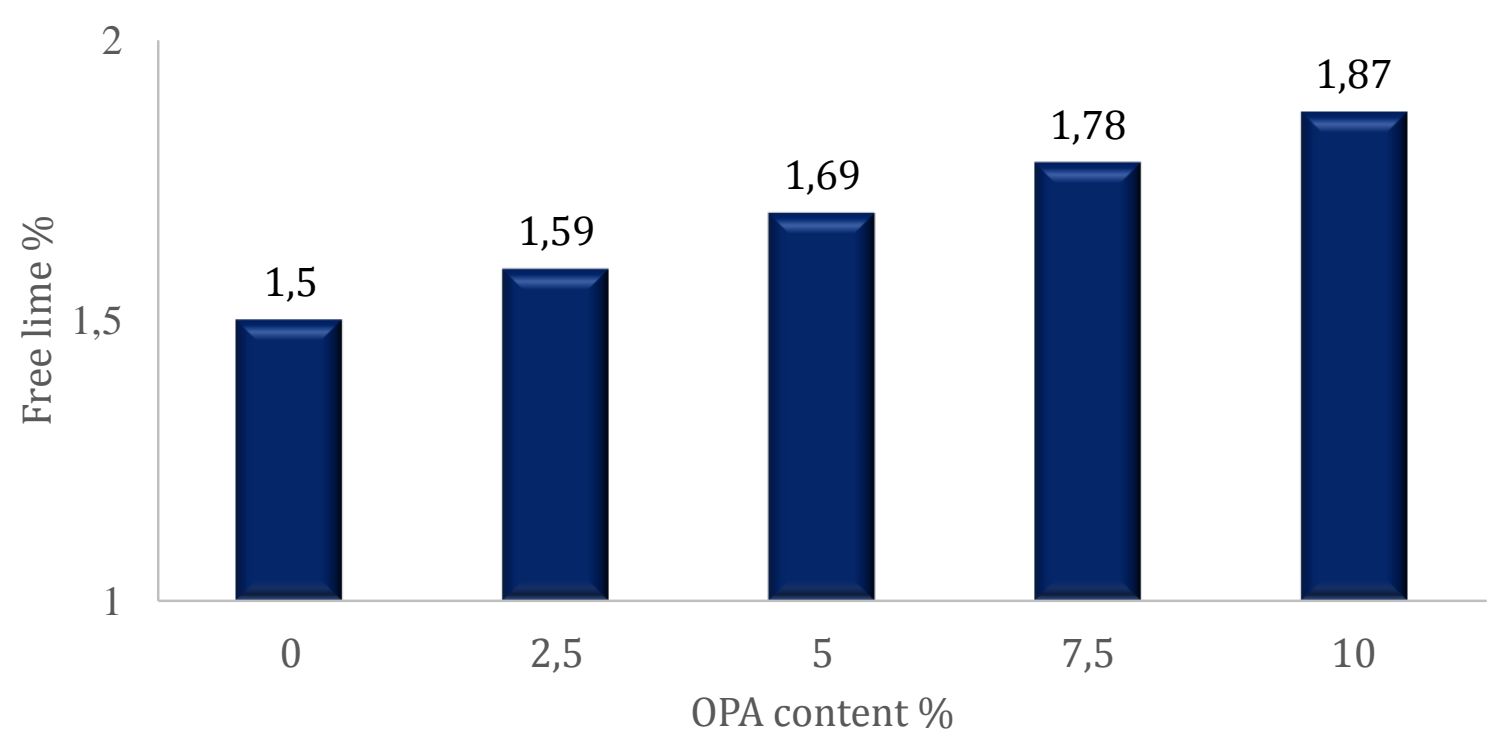

Figure 9 - Effect of OPA content on Free lime of cement blends

\section{CONCLUSION}

The following conclusions on the investigation of OPA as a potential cement replacement material are as follows:

The optimal condition for calcination of orange peel sample was obtained at $600{ }^{\circ} \mathrm{C}$ for 2 hours having obtaining the highest $\mathrm{SiO}_{2}+\mathrm{Al}_{2} \mathrm{O}_{3}+\mathrm{Fe}_{2} \mathrm{O}_{3}$ percentage as $27.70 \%$ as compared to other OPA conditions.

The chemical analysis of OPA via X-ray Fluorescence comprised mainly of lime, silica and potassium oxide with $\mathrm{SiO}_{2}+\mathrm{Al}_{2} \mathrm{O}_{3}+\mathrm{Fe}_{2} \mathrm{O}_{3} \quad(27.70 \%)$ contained less than $70 \%$ with $\mathrm{CaO}$ content > $10 \%$ at $31 \%$ which met Class C; hence the ash does not satisfy as a pozzolan according to ASTM C618-19.

The cement replacement with OPA served as a decelerator in a binary cement due to the significant potassium oxide content and the OPA high LOI of $6.54 \%$ indicating a high degree of unburnt carbon which was responsible for the increase in the water requirement as well as prolonged setting times.

Whereas, OPA also serve as strength aider in a cement replacement as a result of the high $\mathrm{CaO}$ and $\mathrm{SiO}_{2}$ content. The higher the OPA content, the greater the decelerating effect.

An increase in the water demand, setting times and soundness was experienced as the OPA content was increased whereas a decrease in the mortar compressive and flexural strengths were experienced as the cement replacement with OPA content was gradually increased from 0 $10 \%$.

The optimal cement replacement with OPA was obtained at $5 \%$, since the physico-mechanical properties of OPA cement blends deviate not too significantly from OPC properties. OPA cement blends all fell within the ASTM C618-19 requirements for physico-mechanical properties of cement blends.

\section{REFERENCES}

1. Abdel-Shafy, H. I., \& Mansour, M. S. M. (2018). Solid waste issue: Sources, composition, disposal, recycling, and valorization. Egyptian Journal of Petroleum, 27(4), 1275-1290. doi: 10.1016/j.ejpe.2018.07.003

2. Acheampong, A., Adom-Asaomoah, M., Ayarkwa, J., \& Afrifa, R. (2013). Comparative study of the physical properties of Palm kernel shells concrete and normal weight concrete in Ghana. Journal of Science and Multidisciplinary Research, 5(1), 129-146.

3. ASTM International. (2016). Standard Test Method for Amount of Water Required for Normal Consistency of Hydraulic Cement Paste (ASTM C187-16). doi: 10.1520/c0187-16 
4. ASTM International. (2016). Standard Test Method for Compressive Strength of Hydraulic Cement Mortars (Using 2-in. or [50-mm] Cube Specimens) (ASTM C109/C109M-16a). doi: 10.1520/c0109_c0109m-16a

5. ASTM International. (2018). Standard Test Methods for Time of Setting of Hydraulic Cement by Vicat Needle (ASTM C191-18a). doi: 10.1520/c0191-18a

6. ASTM International. (2019). Standard Specification for Blended Hydraulic Cements (ASTM C595/C595M). doi: 10.1520/c0595_c0595m-19

7. ASTM International. (2019). Standard Specification for Coal Fly Ash and Raw or Calcined Natural Pozzolan for Use in Concrete (ASTM C618-19). doi: 10.1520/c0595_c0595m-19

8. Better Meets Realty. (2018, September 16). Waste Pollution: Causes, Sources, Effects \& Solutions. Retrieved from https://www.bettermeetsreality.com/waste-pollution-causes-sources-effectssolutions

9. Bhushan, R., Gochhe, S., Singh, H., \& Bastola, B. (2017). Partial Replacement of Cement by Rice husk ash. International Research Journal of Engineering and Technology, 4(10), 251-256.

10. De Weerdt, K., Kjellsen, K. O., Sellevold, E., \& Justnes, H. (2011). Synergy between fly ash and limestone powder in ternary cements. Cement and Concrete Composites, 33(1), 30-38. doi: 10.1016/j.cemconcomp.2010.09.006

11. Djilas, S., Canadanovic-Brunet, J., \& Cetkovic, G. (2009). By-products of fruits processing as a source of phytochemicals. Chemical Industry and Chemical Engineering Quarterly, 15(4), 191-202. doi: 10.2298/ciceq0904191d

12. Elinwa, A. U., Ejeh, S. P., \& Mamuda, A. M. (2008). Assessing of the fresh concrete properties of selfcompacting concrete containing sawdust ash. Construction and Building Materials, 22(6), 11781182. doi: 10.1016/j.conbuildmat.2007.02.004

13. Espiard, E. (2002). Introduction à la transformation industrielle des fruits. Paris: Tec \&Doc Lavoisier

14. Freeman, E., Gao, Y.-M., Hurt, R., \& Suuberg, E. (1997). Interactions of carbon-containing fly ash with commercial air-entraining admixtures for concrete. Fuel, 76(8), 761-765. doi: 10.1016/s00162361(96)00193-7

15. Georgescu, M., \& Saca, N. (2009). Properties of blended cements with limestone filler and fly ash content. Scientific Bulletin, Series B, 71(3), 11-22.

16. Gowsika, D., Sarankokila, S., \& Sargunan, K. (2014). Experimental investigation of egg shell powder as partial replacement with cement in concrete. International Journal of Engineering Trends and Technology, 14(2), 65-68.

17. Kadi, N., \& Vinod, M. (2015). Influence of Rise Husk Ash on the properties of concrete. Journal of Computer Science and Engineering, 1(5), 75-79.

18. Karthick, J., Jeyanthi R., \& Petchiyammal, M. (2014). Experimental Study on Usage of Egg Shell as Partial Replacement for Sand in Concrete. International Journal of Advanced Research in Education Technology, 1(1), 7-10.

19. Kaya, A. (2010). A study on blended bottom ash cements. Retrieved from https://ru.scribd.com/document/230376452/A-Study-on-Blended-Bottom-Ash-CementsTaban-Kulu-Katk\%C4\%B11\%C4\%B1-Cimentolara-Yonelik-Bir-Cal\%C4\%B1\%C5\%9Fma

20. Külaots, I., Hurt, R. H., \& Suuberg, E. M. (2004). Size distribution of unburned carbon in coal fly ash and its implications. Fuel, 83(2), 223-230. doi: 10.1016/s0016-2361(03)00255-2

21. Lothenbach, B., Le Saout, G., Gallucci, E., \& Scrivener, K. (2008). Influence of limestone on the hydration of Portland cements. Cement and Concrete Research, 38(6), 848-860. doi:

10.1016/j.cemconres.2008.01.002 
22. M'Hiri, N., Ioannou, I., Ghou, M., Mihoubi, B. (2015). Proximate chemical composition of orange peel and variation of phenols and antioxidant activity during convective air drying. Journal of New Sciences, Agriculture and Biotechnology, 9, 881-890.

23. Ma, Y., Chen, J., Liu, D., \& Ye, X. (2009). Simultaneous extraction of phenol compounds of citrus peel extracts: Effect of ultrasound. Ultrason Sonochem, 16, 57-62.

24. Marín, F. R., Soler-Rivas, C., Benavente-García, O., Castillo, J., \& Pérez-Alvarez, J. A. (2007). Byproducts from different citrus processes as a source of customized functional fibres. Food Chemistry, 100(2), 736-741. doi: 10.1016/j.foodchem.2005.04.040

25. Marshall, R. E., \& Farahbakhsh, K. (2013). Systems approaches to integrated solid waste management in developing countries. Waste Management, 33(4), 988-1003. doi: 10.1016/j.wasman.2012.12.023

26. Marthong, C. (2012). Effect of Rice Husk Ash (RHA) as Partial Replacement of Cement on Concrete Properties. International Journal of Engineering Research \& Technology, 1(6), 1-9.

27. Mohamed, A., Dinesh, K., Milan, Ch., \& Vani, G. (2016). Replacement of Cement using Eggshell powder. International Journal of Civil Engineering, 3(3), 1-2.

28. Namasivayam, C., Muniasamy, N., Gayatri, K., Rani, M., \& Ranganathan, K. (1996). Removal of dyes from aqueous solutions by cellulosic waste orange peel. Bioresource Technology, 57(1), 37-43. doi: 10.1016/0960-8524(96)00044-2

29. Olubajo, O., \& Osha, O. (2013). Influence of bottom ash and limestone powder on the properties of ternary cement and mortar. International Journal of Engineering Research and Technology, 2(7), 1201-1212.

30. Olubajo, O., Osha, O., El-Natafty, U., \& Adamu, H. (2017). A study on Coal bottom ash and limestone effects on the hydration and physico-mechanical properties of ternary cement blends. Abubakar Tafawa Balewa University.

31. Raheem, A., \& Adesanya, A. (2011). A study of thermal conductivity of corn cob ash blended cement mortar. The Pacific Journal of Science and Technology, 12(2), 106-111.

32. Santos, C. M., Dweck, J., Viotto, R. S., Rosa, A. H., \& de Morais, L. C. (2015). Application of orange peel waste in the production of solid biofuels and biosorbents. Bioresource Technology, 196, 469-479. doi: 10.1016/j.biortech.2015.07.114

33. Sharma, A., Ameta, R., \& Ameta, S. (2013). Orange peel as Alternate Fuel in Clinkerization. Scientific Reviews \& Chemical Communication, 3(2), 110-119.

34. United Sates Department of Agriculture. (2019). Citrus: World Markets and Trade. Retrieved from http://www.fas.usda.gov/data/citrus-world-markets-and-trade

35. Yerramala, A. (2014). Properties of concrete with eggshell powder as cement replacement. The Indian Concrete Journal, 88(10), 94-105. 